\title{
A INVALIDAÇÃO DOS ATOS ADMINISTRATIVOS E A MODULAÇÃO TEMPORAL DE SEUS EFEITOS
}

\section{INVALIDATION OF ADMINISTRATIVE ACTS AND TEMPORAL MODULATION OF THEIR EFFECTS}

\author{
Clarissa Sampaio Silva ${ }^{1}$ \\ Ivson Antonio de Souza Meireles ${ }^{2}$
}

\section{RESUMO}

O presente trabalho tem por objetivo analisar, dentro da temática da invalidação dos atos administrativos, a possível modulação temporal de seus efeitos, os quais são normalmente retroativos. A declaração de nulidade do ato, mesmo dentro do prazo estabelecido em lei, traz, em diversas situações analisadas na jurisprudência dos Tribunais judiciais, do Tribunal de Contas, e também na doutrina, ofensas a princípios constitucionais da Administração Pública, como a razoabilidade e a proporcionalidade, de modo que, com inspiração na modulação da declaração de inconstitucionalidade das leis, podem ser buscadas soluções semelhantes, com exigências acrescidas de motivação pela Administração Pública.

Palavras-chave: Ato Administrativo. Invalidação. Modulação dos Efeitos.

\begin{abstract}
This study aims to analyze, within the theme of invalidation of administrative acts, the possible temporal modulation effects, which are usually retroactive. The act of declaration of nullity, even within the period established by law, brings in different situations analyzed in the jurisprudence of judicial courts, the Court of Auditors, and also the doctrine, offenses against constitutional principles of public administration, as the reasonableness and proportionality, so that inspired in the modulation of the unconstitutionality of laws declaration, similar solutions can be sought, with increased demands of motivation by the Government.
\end{abstract}

Keywords: Administrative act. Invalidation. Modulating the effects.

\footnotetext{
${ }^{1}$ Doutora em Direito pela Universidade de Lisboa. Professora da Universidade de Fortaleza - FUMEC, Ceara (Brasil).

E-mail: sampaioclarissa@hotmail.com

${ }^{2}$ Mestre em Direito Constitucional pela Universidade de Fortaleza - FUMEC, Ceara (Brasil).
} 


\section{INTRODUÇÃO}

A Lei do Processo Administrativo (Lei ${ }^{\circ}$ 9.784/99) incluiu em suas disposições o tema do desfazimento dos atos administrativos, representado pela invalidação e pela revogação, além de medida para superar vícios sanáveis, no caso, a convalidação.

No tocante à invalidação dos atos administrativos, a legislação em comento estabelece a competência para a Administração Pública desfazer seus próprios atos por vício de legalidade, a fixação do prazo para exercício de tal competência, além da definição da natureza jurídica daquele.

O esquema trazido por referido diploma legal atendeu aos reclames da doutrina administrativista que apontava a necessidade de reconhecimento de limite temporal à possibilidade de a Administração Pública voltar-se contra seus próprios atos, resolvendo, ainda, a discussão sobre o adequado prazo a ser adotado.

Apesar de contemplar importantes tópicos relativos a tal matéria, a disciplina da Lei 9.784/99revela-se insuficiente em determinadas situações, para tratar, de forma coetânea com a ordem jurídica constitucional, os conflitos que podem surgir em razão dos atos de invalidação praticados pela Administração Pública, especialmente no que diz respeito ao tratamento das consequências produzidas pelos atos inválidos, ou seja, aos efeitos da invalidação.

Como regra, a invalidação do ato administrativo com vícios que geram sua nulidade deve levar à desconstituição dos efeitos que lhes são decorrentes, provocando o retorno da situação anterior à prática do ato. Todavia, a análise de casos retirados de decisões do Poder Judiciário, do Tribunal de Contas e outros apontados pela doutrina revelam a necessidade de se proceder à modulação temporal dos efeitos de declaração de nulidade, tal como é feito no tocante à declaração de inconstitucionalidade das leis e atos normativos.

Constitui objetivo do presente artigo, originário de pesquisa de natureza qualitativa, identificar, em decisões judiciais, do Tribunal de Contas da União e na doutrina, casos em que a adoção da retroatividade total dos efeitos da invalidação de atos administrativos gera situações - em decorrência de ações da própria Administração Pública - incompassíveis com os princípios constitucionais e com os direitos fundamentais, de modo a demonstrar a necessidade de elaboração e justificação de ser-lhes dado tratamento diverso. 
Referido tratamento, por sua vez, demanda o enfrentamento de duas importantes questões, a saber: a) qual o fundamento normativo para a modulação temporal dos efeitos da invalidação dos atos administrativos; b) a quem pertence a competência para definir os marcos temporais dos efeitos da invalidação.

A metodologia aplicada consiste em um estudo bibliográfico, tendo em vista a análise de dados em livros, decisões judiciais e dos Tribunais de Contas. Esse mecanismo se revela imprescindível para a adequação da pesquisa às pretensas contribuições práticas e ao desenvolvimento dos estudos acerca da modulação dos efeitos da invalidação dos atos administrativos, de forma a repercutir na dinâmica da Administração Pública.

\section{A INVALIDAÇÃO DOS ATOS ADMINISTRATIVOS E SUA REGULAÇÃO} ATUAL

"Verdadeira flor de estufa da dogmática administrativa clássica"consoante aduz Silva (1996, p. 70), os atos administrativos, a despeito da importância atualmente atribuída a figuras como o processo administrativo, preservam a qualidade decisória final da Administração Pública na realização das suas atividades,detendo importante papel, assim, no âmbito do exercício da função administrativa.

A exemplo, convém ressaltar que é na condição de ato administrativoque as decisões do Tribunal de Contas "de que resulte a imputação de débito ou multa terão eficácia de título executivo", conforme artigo 71, $\S 3^{\circ}$, da Constituição Federal. Igualmente, as situações caracterizadoras de improbidade administrativa, nos termos da Lei ${ }^{\circ}$ 8.429/92, decorrem de atos administrativos, restando elencados aqueles que importam enriquecimento ilícito (artigo $9^{\circ}$ ); aqueles que causam prejuízo ao erário (artigo 10) e os que atentam contra os princípios da Administração Pública (artigo 11).

Complementarmente, o tema da invalidação tratado pela Lei $n^{\circ}$ 9.784/99, apresentase sob a ótica dos atos administrativos, reforçando a posição central dos mesmos, ademais, para o ordenamento jurídico pátrio.

Dentro da perspectiva da "tendencial irrevogabilidade dos atos administrativos", de acordo com Canotilho(1997, p. 258), em razão dos princípios da segurança jurídica, proteção da confiança e boa-fé dos administrados, a Lei do Processo Administrativo Federal trouxe 
disposições sobre a invalidação e revogação dos referidos atos, até então inexistentes na ordem jurídica brasileira, com tratamento destinado apenas pela Súmula 473 do Supremo Tribunal Federal, a qual possui a seguinte redação:

A Administração pode anular seus próprios atos, quando eivados de vícios que os tornem ilegais, porque deles não se originam direitos; ou revogá-los, por motivo de conveniência e oportunidade, respeitados os direitos adquiridos e respeitadas em todos os casos, a apreciação judicial.

Os atos administrativos são normalmente situados no patamar infralegal, pois são providências de cunho jurídico editados pela Administração Pública para concretizar as previsões contidas nas leis, de modo que as suas hipóteses de invalidação, de acordo com a disciplina da Lei no 9.784/99, referem-se à presença do vício de legalidade. Essa mácula deve atingir um ou alguns dos pressupostos ou elementos, quais sejam, a competência, o objeto ou conteúdo, a forma, a finalidade e o motivo. ${ }^{3}$ A disciplina legal sobre a invalidação é disposta da seguinte maneira pelo referido instrumento:

Art. 53. A Administração deve anular seus próprios atos, quando eivados de vício de legalidade, e pode revogá-los por motivo de conveniência ou oportunidade, respeitados os direitos adquiridos.

Seguindo-se ao tratamento da anulação, condicionando-a a marco temporal para a sua realização, a Lei no 9.784/99 expõe:

Art. 54. O direito da Administração de anular os atos administrativos de que decorram efeitos favoráveis para os destinatários decai em cinco anos, contados da data em que foram praticados, salvo comprovada má-fé.

$\S 1$ o No caso de efeitos patrimoniais contínuos, o prazo de decadência contar-se-á da percepção do primeiro pagamento.

$\S 2$ o Considera-se exercício do direito de anular qualquer medida de autoridade administrativa que importe impugnação à validade do ato.

Considerando o esquema trazido pelo referido diploma normativo para a invalidação do ato administrativo, tem-se que o exercício de tal competência pela Administração Pública encontra como limite o decurso de tempo, com prazo de natureza decadencial, no caso, de cinco anos, aliado ao surgimento de situações ampliativas de direito - geradas por atos administrativos favoráveis - e à presença da boa-fé, pois a estabilização de ato viciado justifica-se para a proteção da segurança jurídica e da confiança na atuação do Poder Público, a qual apenas pode se dar, obviamente, diante de tal condição subjetiva.

\footnotetext{
${ }^{3}$ No plano normativo, os possíveis vícios existentes sobre os atos administrativos encontram-se elencados no $\operatorname{art.} 2^{\circ}$ da Lei no 4.717/65 (Lei da Ação Popular).
} 
Assim, a regra é a de que, presente vício de legalidade em ato administrativo favorável, para cuja prática não tenha concorrido má-fé do beneficiário, do servidor público ou de ambos, uma vez transcorrido o prazo de 5 (cinco) anos, encontra-se a Administração Pública impedida de se voltar contra ele por meio da invalidação, a qual não prescinde, em todo caso, da regular instauração de processo administrativo. ${ }^{4}$

Fazendo raciocínio inverso, não tendo decorrido inteiramente referido prazo, deverá ser realizada a invalidação, cujos efeitos são, em regra,extunc.E, na hipótese da presença da condição subjetiva da má-fé, não incidem tais limites para o desfazimento do ato por tal via.

Necessário considerar ainda a possibilidade de convalidação do ato viciado, na hipótese de "vícios sanáveis", nos termos do artigo 55, da Lei n 9.784/99, entendendo a doutrina que, quando cabível, deve ser ela realizada, quer por prestigiar o princípio da segurança jurídica, conforme preleciona Mello (2005), quer por representar o meio menos oneroso,conforme o entendimento de Silva (2001), ou então, que a Administração Pública precisa realizar uma ponderação para escolher o meio de correção do ato viciado, de acordo comMartins (2011).

A invalidação é tratada como ato declaratório desconstitutivo de direito, pois desfaz os efeitos já produzidos e retira a aptidão para a produção de efeitos futuros, de acordo com Sunfeld (1990), de modo que, normalmente, retira de circulação tanto o próprio ato quanto os seus efeitos, promovendo o retorno ao status quo ${ }^{5}$ anterior à sua prática.

Considera-se, portanto, que os efeitos da invalidação são retroativos, fulminando as consequências originadas do ato inválido (MELLO, 2005), entendendo-se que a retroatividade da invalidação tem função tanto destrutiva quanto construtiva, consoante os ensinamentos de Medauar (2015). Pela primeira vertente, tem-se o desaparecimento de faculdades, vantagens ou prerrogativas que seriam decorrentes do ato viciado, como a invalidação de um ato de promoção de servidor público ou de licença ambiental. Na segunda vertente, ao revés, além da eliminação do ato viciado, devem ser praticados outros atos que sejam necessários à

\footnotetext{
${ }^{4}$ A jurisprudência, tanto do Supremo Tribunal Federal quanto do Superior Tribunal de Justiça são uníssonas em exigir a prévia instauração de processo administrativo para invalidação de atos administrativos dos quais decorram efeitos favoráveis aos administrados. Conferir, entre outros arestos: (STF- RMS 25.849 AgR/DF, RMS 25714; RMS 26097. STJ- Resp. 658.130/SP, MS 8627/DF, MS 8832/DF) Sobre a compreensão do processo administrativo como limite formal à invalidação dos atos administrativos, conferir Silva (2001).

${ }^{5}$ Sobre o caráter retroativo da invalidação ver, na jurisprudência do STJ: RMS 22141/RS, DJE 18/09/2008.
} 
restituição ao estado anterior à sua prática, como a invalidação de ato que indeferiu a inscrição em concurso público, na exemplificação de Medauar (2015).

Trata-se da aplicação da mesma lógica utilizada no tocante à lei inconstitucional, a qual é considerada nula desde a sua edição, de acordo com a tradicional doutrina norte americana incorporada ao Direito Constitucional pátrio ${ }^{6}$.

Todavia, há diversas situações em que semelhante diretrizdeve se amoldar à preservação dos princípios constitucionais, de forma a alcançar os menores prejuízos ao seu sistema de valores e à coletividade. Nessa perspectiva, os marcos temporais para a fixação dos efeitos da invalidação adequam-se à peculiaridade de cada evento, consoante é possível verificar a seguir.

\section{SITUAÇÕES ENSEJADORAS DE INVALIDAÇÃO IRRETROATIVA OU ESTABELECIMENTO DE MARCO TEMPORAL DIVERSO PARA A DEFLAGRAÇÃO DE SEUS EFEITOS}

A despeito da regra geral da retroatividade da invalidação de atos administrativos, faz-se possível identificar em decisões do órgão de controle externo, da Administração Pública, do Poder Judiciário, bem como em exemplos colhidos da doutrina, a existência de invalidações irretroativas ou de retroatividade realizada a partir de dado momento, sendo oportuno, de logo, distinguir tais situações daquelas em que seja possível haver a convalidação do ato, já que, nesse último caso, vislumbra-se a correção dos seus defeitos sanáveis, de forma a aperfeiçoar a produção dos seus resultados.

Como hipótese de invalidação sem efeitos retroativos tem-se a percepção, por parte de servidor público, de vantagens financeiras recebidas de boa-fé, em virtude de erro escusável na interpretação da lei, caso em que, com base em entendimento do Tribunal de Contas da União, não é realizada a reposição ao erário, nos termos da Súmula no 249 , in verbis:

É dispensada a reposição de importâncias indevidamente percebidas, de boa-fé, por servidores ativos e inativos, e pensionistas, em virtude de erro escusável de interpretação de lei por parte doórgão/entidade, ou por parte de autoridade legalmente investida em função de orientação e supervisão, à vista da presunção de legalidade do ato administrativo e do caráter alimentar das parcelas salariais.

\footnotetext{
${ }^{6}$ Consoante destaca Mendes et al. (2007) a nulidade da lei por inconstitucionalidade foi desenvolvida, inicialmente, por Rui Barbosa, ao concluir, fazendo referência ao regime americano, estar-se, em tal situação, apenas diante de uma consequência resultante da "própria essência do sistema."
} 
Pelas mesmas razões, o início da prolação dos efeitos da decisão de invalidação pode ser projetado para momento posterior, como é o casodo julgamento, pelo Tribunal de Contas, da ilegalidade de concessões de reforma, aposentadoria e pensão, em que há a ressalva vinculada até a "data de conhecimento da decisão pelo órgão competente", das importâncias pagas de boa-fé, a qual cessa, decerto, com a prolação daquela, também de acordo com entendimento sumulado pelo referido Tribunal:

Súmula 106:O julgamento, pela ilegalidade, das concessões de reforma, aposentadoria e pensão, não implica por si só a obrigatoriedade da reposição das importâncias já recebidas de boa-fé, até a data do conhecimento da decisão pelo órgão competente.

Além das situações descritas nas súmulas do Tribunal de Contas da União, é possível citar outras em que se apresenta razoável a manutenção dos efeitos do ato inválido, como é o caso descrito pela doutrina de acumulação ilícita, embora de boa-fé, de dois cargos públicos e o aproveitamento, para fins licenças, férias, aposentadoria, do tempo de serviço no segundo cargo no qual, empós, tenha havido a exoneração a pedido. ${ }^{7}$

Ora, considerando ter havido por parte do servidor no desempenho da função recolhimento de contribuição previdenciária, não se coaduna com o bom senso que seja possível à Administração desconsiderá-los, o que implicaria, inclusive, enriquecimento ilícito por parte da mesma, sendo suficiente, assim, o tratamento da questão sob a ótica da razoabilidade.

Outra situação paradigmática em que se pode cogitar da manutenção de efeitos de ato viciado seria a hipótese de invalidação de ato administrativo de incorporação pela CONITEC Comissão Nacional de Incorporação de Tecnologia, órgão do Ministério da Saúde, de dado medicamento ao Sistema Único de Saúde, com base no artigo 19, da Lei n ${ }^{\circ} 12.401 / 2011^{8}$, e as situações surgidas em virtude da aquisição e dispensa daquele, pela Administração Pública, aos usuários do sistema, de modo que, ao menos em relação a eles, não se há de cogitar da devolução in naturaou em pecúnia daquele, pois tal medida tanto iria de encontro ao bom senso, trazendo, ainda, mais desvantagens do que vantagens, mirando-se as medidas, inclusive judiciais, que se fariam necessárias para a recomposição do status quo ante.

\footnotetext{
7 Tal hipótese poderia surgir, consoante explana Furtado (2010) por ocasião da assunção de novo cargo público por servidor, de cujo primeiro cargo estivesse, apenas, no gozo de licença sem vencimento, possibilidade admitida, durante certo tempo, mas atualmente tida como ilícita.

${ }^{8}$ Texto integral em www.planalto.gov.br
} 
Pode ser citado, ademais, o clássico caso, tratado pelo Supremo Tribunal Federal no RE $n^{\circ} 78.594 / S P,{ }^{9}$ da invalidação de ato de nomeação de servidor público, por vício na investidura, ressalvando-se, todavia, a validade dos atos por ele praticados. Tem-se aqui invalidação irretroativa, em que os efeitos provocados por ato inválido são mantidos, o que deve se estender, logicamente, àqueles de natureza remuneratória, de modo que aqueles que exerceram as atribuições do cargo público mediante investidura inválida, não podem, sob pena de autorização de enriquecimento ilícito em prol da Administração Pública, deixarem de ser remunerados pelo exercício da função pública, mormente não se cogitando de qualquer expediente fraudulento para a concretização das nomeações posteriormente invalidadas.

Convém assinalar, outrossim, a declaração de inconstitucionalidade pelo Tribunal de Justiça do Estado do Paraná do artigo 11, inciso XV, da Lei Orgânica do Município de Curitiba (ADI no 52764-2), assim como dos Decretos Municipais no 795/95 e 696/95, responsáveis por atribuir à Sociedade de Economia Mista municipal poderes para a disciplina do trânsito, a exemplo da instituição de penalidades e arrecadação de multa.

Com fulcro na competência constitucional da União para legislar privativamente sobre trânsito e transportes, bem como da competência do Estado do Paraná para exercer as prerrogativas de Poder de Polícia relativas ao trânsito, o Tribunal atribuiu efeitos ex nuncà decisão declaratória de inconstitucionalidade, mantendo-se os atos praticados pela Sociedade de Economia Mista municipal até a publicação do acórdão, não obstante o reconhecimento da existência de vícios.

Cabe citar também o julgamento pelo Supremo Tribunal Federal dos Embargos de Declaração no Recurso Extraordinário $n^{\circ} 600.885 /$ RS.Na ocasião, tendo em vista o princípio da segurança jurídica, a Corte modulou os efeitos da não recepção Constitucional do termo "nos regulamentos da Marinha, do Exército e da Aeronáutica", prevista no artigo 10, da Lei no 6.880/1980, para estabelecer que a disposição de critérios de idade para o ingresso na carreira militar não prescinde de lei em seu sentido formal e material, conforme artigo $142, \S 3^{\circ}$, inciso X, da Constituição Federal.

Nessa acepção, deliberou-se por atribuir efeitos prospectivos à presente decisão, de forma a não prejudicar o planejamento administrativo realizado por meio dos servidores

\footnotetext{
9 "Funcionário público. Exercício da função de Oficial de Justiça. Ilegalidade da investidura do funcionário público na função de Oficial de Justiça, em razão da declaração de inconstitucionalidade da lei estadual que autorizou tal designação, o ato por ele praticado é válido.”
} 
militares que ingressaram na carreira em conformidade com os critérios de idade previstos em regulamento próprio das Forças Armadas, ou que, em razão dos concursos a serem realizados durante o respectivo ano em curso, integrariam o quadro. Ou seja, a invalidação do regulamento militar, ato administrativo normativo, teve seus efeitos protraídos para outro momento.

\subsection{Distinções entre situações provocadas pela própria Administração e aquelas decorrentes de atuação do Poder Judiciário}

Em tema de manutenção dos efeitos atos inválidos cabe a indagação se tal postura, por parte da Administração Pública, implicaria a adoção da teoria do fato consumado, cuja elaboração é oriunda da jurisprudência do Supremo Tribunal Federal, a propósito da então controvérsia existente sobre a possibilidade de os regimentos internos das universidades públicas estabelecerem nota mínima para aprovação dos alunos e as situações criadas por decisões judiciais que afastavam tal exigência e davam ensejo à conclusão do curso e expedição de diplomas universitários. ${ }^{10}$

A teoria do fato consumado tem como particularidade, além da consolidação pelo decurso de tempo de situações ampliativas de vantagens, o fato de terem sido produzidas por força de decisão judicial, de modo que, se de um lado, o interessado encontrava-se amparado por ato do Poder Judiciário, de outro, havia, desde sempre, resistênciapor parte da Administração Pública à pretensão deduzida em juízo.

Assim, no tocantea esta última, não há que se falar em dever de manutenção dos efeitos do ato invalidado judicialmente, pois tal postura não seria compatível com a tese jurídica defendida nessa instância, não sendo possível deixar de considerar que apenas nas situações expressamente autorizadas pelo ordenamento é que advogado público pode transigir em juízo ou deixar de recorrer, quer em virtude da indisponibilidade do interesse público, quer em virtude da impessoalidade, de modo a evitar decisões casuísticas. ${ }^{11}$

Pode-se aqui fazer paralelo com a situação decorrente do pagamento de vantagem remuneratória a servidor público por força de decisão judicial posteriormente objeto de

10 Sobre o histórico da teoria do fato consumado e seus desdobramentos atuais, ver Martins (2008).

11 Sobre a realização de acordos em juízo pela União, ver o art. 44 da Lei n. 13.140/2015 (Lei da Mediação). 
reforma, caso em que, em decisão recente, o Supremo Tribunal Federal entendeu que, diante da resistência oferecida pela Administração Pública, não se configura a boa-fé do beneficiário, impondo-se, nesse caso, a devolução das parcelas recebidas. ${ }^{12}$

Já quanto ao Poder Judiciário a questão se apresenta de outra forma, pois, em virtude de a situação consolidada ser decorrente de uma atuação sua, cabe-lhe dar a melhor disciplina à luz dos princípios da razoabilidade e da proporcionalidade à situação jurídica surgida em virtude do tempo do processo, qual seja, a manutenção ou não dos efeitos de decisão sua, a despeito do julgamento definitivo de improcedência do feito ${ }^{13}$.

\section{DOS FUNDAMENTOS E COMPETÊNCIA PARA MODULAÇÃO DOS EFEITOS DA INVALIDAÇÃO DE ATO ADMINISTRATIVO}

12 Mandado de Segurança no 29.247- Rio Grande do Norte. "LEGITIMAÇÃO - MANDADO DE SEGURANÇA. Define-a a autoria do ato atacado. Sendo cogente, considerado o Tribunal de Contas da União e o órgão da administração pública, é legitimado para figurar como órgão impetrado o primeiro.DEVIDO PROCESSO LEGAL - ATO ADMINISTRATIVO - INEXISTÊNCIA. Uma vez inexistente ato administrativo gerador de situação constituída, descabe cogitar do contraditório, isso em razão daausência de acusado ou de litigante.LIMINAR - EFICÁCIA. A liminar é de natureza precária e efêmera.Surte efeitos apenas enquanto está em vigor.ADMINISTRAÇÃO PÚBLICA - VALORES - RECEBIMENTO -BOA-FÉ. Ante o princípio da legalidade estrita, não se pode dizer de boafé no que percebidas, em virtude da eficácia de medida acauteladora, prestações sucessivas.MAGISTRATURA - BENEFÍCIOS. Os benefícios da magistratura estão previstos de forma exaustiva na Lei Orgânica regedora." Precedente: Mandado de Segurança $n^{\circ} 24.353$, relatora ministra Ellen Gracie.

${ }^{13}$ Em acórdão envolvendo o tema, o Superior Tribunal de Justiça, apesar de não endossar a teoria do fato consumado para assegurar a manutenção dos efeitos de decisão judicial, posteriormente reformada, que concedera a candidata nomeação em concurso público a despeito de não aprovação no concurso público de provas e títulos, entendeu que o afastamento do cargo não poderia se dar sem o trânsito em julgado do acórdão desfavorável. A manutenção do afastamento impugnado, nos termos do acórdão, "importa desprestígio aos princípios constitucionais daeficiência e da razoabilidade, já que não há sentido no afastamento imediato da impetrante do cargo para o qual já está desempenhando suas atribuições há mais de 15 anos, período no qual, segundo consta do Relatório emitido pelo Grupo de Trabalho, constituído pela Portaria GM n. 1.119, de 19.12.2008, foi capacitada pelaAdministração Pública e adquiriu vasto conhecimento teórico e prático nas ações da Auditoria-Fiscal do Trabalho,para,posteriormente, acaso seja mantida a sentença de procedência da sentença, determinar-se a reintegração da servidora ao cargo de Auditor Fiscal do Trabalho. Assim, a manutenção do impetrante no cargo de até o trânsito em julgado da ação ordinária parecer ser, neste momento, a solução que melhor atende ao interesse público." MS n ${ }^{\circ} 15.920 / \mathrm{DF}$. No caso em apreço, realizou o STJ, claramente, juízos de razoabilidade e proporcionalidade para decidir pela manutenção, até o julgamento final da decisão de improcedência do feito, da autora no cargo público, pois, o seu afastamento, após o longo período de exercício, com aquisição de vasta experiência, aliado ao investimento em sua formação pela Administração Pública, além de ir de encontro ao bom senso, traz mais desvantagens do que vantagens. No sentido de que "a aplicação da teoria do fato consumado em matéria de concurso público requer o cumprimento dos requisitos legalmente estabelecidos para a investidura no cargo pretendido" ver a decisão proferida, também pelo STJ, no MS no 319.88 . 
Consoante se referiu, determinadas situações não acham respostas completamente satisfatórias na regulação da invalidação com caráter absolutamente retroativa, ante o risco de lesão a direitos fundamentais e aos princípios constitucionais.

Serão abordados, a seguir, os fundamentos que, dentro do tema dos efeitos da invalidação dos atos administrativos, autorizam a busca das soluções mais compatíveis com o conflito de princípios presentes em tais situações, cujas soluções, considerando sua estrutura abstrata e sua carga axiológica, exigem inevitáveis ponderações, sendo insuficiente o método jurídico da subsunção.

Com efeito, de acordo com a concepção dos princípios como normas jurídicas,a aplicação deles difere daquela atribuída às regras, vinculada ao entendimento de Dworkin (1999), tendo em vista a estrutura abstrata e carga de valores que carregam, de modo que admitem vários graus de concretização, fugindo, assim, os conflitos de natureza principiológica da proposta do "tudo ou nada", exigindo, invariavelmente, o recurso à ponderação.

Em se tratando da invalidação dos atos administrativos, os conflitos são representados, basicamente, pela necessidade de proteção da confiança e boa-fé dos cidadãos, como manifestação do princípio da moralidade administrativa, segundo Moraes (1999), além da segurança jurídica, subprincípio do Estado de Direito,bem como dos princípios da razoabilidade e da proporcionalidade em confronto com a legalidade, a qual, também, possui status de princípio.

Por outro lado, fazendo-se a analogia entre o controle concentrado ou difuso de constitucionalidade das leis e o controle dos atos administrativos, segundo Martins (2008), chega-se à possibilidade de ponderação das consequências da declaração de nulidade.

Convém assinalar, nesse sentido, que a tese da nulidade absoluta das leis inconstitucionais veio a conhecer mitigação com a edição da Lei $n^{\circ}$ 9.868, de 10 de novembro de 1999, cujo artigo 27 permite a modulação temporal dos efeitos da declaração de inconstitucionalidade, consoante se pode verificar:

Ao declarar a inconstitucionalidade de lei ou ato normativo, e tendo em vista razões de segurança jurídica ou de excepcional interesse social, poderá o Supremo Tribunal Federal, por maioria de dois terços de seus membros, restringir os efeitos daquela declaração ou decidir que ela só tenha eficácia a partir de seu trânsito em julgado ou de outro momento que venha a ser fixado. 
As mesmas razões que levam à estabilização do ato praticado com vício pelo decurso de tempo podem levar à necessidade de, nada obstanteo exercício da invalidação, ainda que dentro do prazo legal, serem mantidos todos ou alguns dos efeitos daquele, podendo ser realizada, aqui, clara analogia com a situação da lei inconstitucional.

Verifica-se tais hipóteses quando a desconstituição dos efeitos produzir situação ora atentatória à boa-fé dos atingidos, ora causadora de intolerável injustiça, avaliada sob as óticas da razoabilidade e da proporcionalidade, que ensejarão, respectivamente, a prolação de decisão que prestigie o bom senso do "auditório" ao qual ela se dirige, bem como a melhor ponderaçãodos bens e valores em questão.

Com efeito, sob a ótica da razoabilidadeaprecia-se a aceitabilidade social de determinada medida administrativa, por sua coadunação com os padrões vigentes em dada sociedade, em determinada época, tendo tal juízo feição eminentemente negativa.Já a ótica da proporcionalidade, de feição positiva, enseja, em seu sentido estrito, a ponderação de princípios em conflito. ${ }^{14}$

Dentro de tal perspectiva é que a invalidação de ato administrativo pode tanto manter todos ou alguns efeitos do ato invalidado, assomando, assim, como total ou parcialmente irretroativa, como também pode estabelecer que aqueles permanecerão até determinado momento posterior à prolação da decisão.

Martins (2008, p.421), nesse sentido, aduz:

\begin{abstract}
Admite-se a invalidação parcialmente retroativa ou pro futuro, além da invalidação totalmente retroativa e irretroativa. Admite-se no plano teórico, uma situação em que os princípios incidentes exijam a manutenção dos efeitos do ato inválido: (1) até data da prolação da decisão; (2) até determinada data posterior à edição do ato inválido, mas anterior à prolação da decisão; (3) até determinada data posterior à prolação da decisão. E a partir dessa data exijam a retirada do ato (e dos respectivos efeitos) do sistema jurídico. Enfim, a invalidação pode ser ex nunc, extunc e ab initio, extunc e não $a b$ initio; pro futuro.
\end{abstract}

\footnotetext{
14 O princípio da razoabilidade possui como fundamento na ordem constitucional o art. 5o, LIV (devido processo legal em sentido material) e o da proporcionalidade, além daquela sede material, e a cláusula do Estado de Direito. Tais princípios são expressamente previstos no art. $2^{\circ}$ da Lei $n^{\circ} 9.784 / 99$. A proporcionalidade e a razoabilidade ensejam,segundo Moraes (1999) o teste da racionalidade de dada decisão, a pertinência dos elementos eleitos pela autoridade decisória para deliberar sobre a questão, a envolver as noções de adequação e exigibilidade. Todavia, nem a razoabilidade enseja o último teste da proporcionalidade, consistente na ponderação, e nem proporcionalidade enseja a observância do senso comum. Sobre o tema, ver Braga (2003).
} 
Mello (2005, p. 434) também admite que, embora a regra seja a invalidação com efeitos retroativos, tal não se dá em todas as situações, podendo ser mantidos efeitos do ato viciado “em nome do princípio da boa-fé e da vedação do enriquecimento ilícito."

E, nesse aspecto, com a ampliação das pautas de atuação da Administração Pública, a qual não pode mais se centrar apenas na legalidade, na medida em que a lei perde a "supremacia de divindade" usufruída no Estado Liberal,conforme as lições de Otero (2003, p.156), tendo em vista o surgimento de textos constitucionais mais densos e enriquecidos de princípios que representam uma conciliação entre interesses conflitantes, dotados de ductibilidade, de acordo com o elenco normativo para fundamentar decisão administrativa de modulação dos efeitos da invalidação é, decerto, bem maior (ZAGREBELSKY, 1992).

Tal mudança de paradigma acarreta, por sua vez, o acesso direto da Administração Pública à ordem constitucional, aos direitos fundamentais, que gozam de aplicabilidade direta e imediata, nos termos do artigo $5^{\circ}, \S 1^{\circ}$, da Constituição Federal, bem como aos princípios da razoabilidade e da proporcionalidade.

Por outro lado, no plano legal, não há definição expressa do marco temporal dos efeitos da invalidação, de modo que a manutenção de todos ou alguns efeitos de atos viciados não constitui postura contra legem, assim como não constituiafastamento de aplicação de lei para a aplicação de princípio.

Faz-se relevante ressaltar, ainda, que a própria Lei $n^{\circ}$ 9.784/99 estabelece como critérios a serem observados nos processos administrativos, a "atuação conforme a lei e o Direito" (artigo $2^{\circ}$, inciso I) e a "adequação entre os meios e fins, vedada a imposição de obrigações, restrições e sanções em medida superior àquela estritamente necessária ao atendimento do interesse público" (artigo $2^{\circ}$, inciso VI), o que corresponde ao princípio da proporcionalidade.

São os referidos fundamentos que autorizam a modulação temporal dos efeitos da invalidação dos atos administrativos pela própria Administração Pública, haja vista que, na medida em que ela possui competência para proceder ao desfazimento de seus próprios atos, para fins de recomposição da ordem jurídica, de forma a abrigar os princípios constitucionais, deve aplicálos nas situações que os reclamem.

Faz-se imprescindível, todavia, alertar para a necessidade de circunstanciada motivação sobre as razões de manutenção de todos ou de alguns efeitos de ato administrativo que tenha sido 
objeto de invalidação, de modo a se evitar casuísmos e violações ao princípio da impessoalidade.

Importante assinalar, outrossim, que nos termos do artigo 50, inciso VIII, da Lei $n^{\circ}$ 9.784/99 são de motivação obrigatória os atos que "importem anulação, revogação, suspensão ou convalidação de ato administrativo", a qual deve contemplar, de maneira pormenorizada, as razões fáticas e jurídicas que ensejam a permanência de efeitos de ato nulo, propiciando, assim, a possibilidade de controle, de acconuntability da decisão administrativa, tanto pela sociedade quanto pelos órgão de controle interno e externo da Administração Pública, com destaque para o Tribunal de Contas.

Deve ser considerada, por fim, a situação de terceiros eventualmente atingidos pela manutenção de efeitos do ato invalidado, de modo a que possam, antes da decisão administrativa, oferecer a impugnação que entenderem pertinente.

\section{CONCLUSÃO}

A figura do ato administrativo segue com a devida importância no âmbito da função administrativa, tanto que a temática da invalidação, disciplinada pela Lei $n^{\circ} 9.784 / 99$, é feita a partir dela.

Referida legislação, apesar de contemplar tópicos essências à matéria, como a definição da competência da Administração Pública para proceder à invalidação dos atos administrativos, o prazo para fazê-la, sua natureza jurídica e seu termo inicial, não trata dos efeitos daquela no que diz respeito à sua projeção temporal, ou seja, se retroativos ou irretroativos, embora a regra seja a de que a nulidade do ato leva à necessidade de desconstituição dos seus efeitos, em analogia à declaração de inconstitucionalidade da lei.

A análise de decisões do Tribunal de Contas da União, do Poder Judiciário, bem como exemplos trazidos pela doutrina demonstram, todavia, que há invalidações irretroativas ou então retroativas a partir de determinado marco, devendo-se, contudo, distinguir as situações geradas por atuação da Administração Pública daquelas decorrentes de decisões judiciais que demandem tratamento diferenciado no tocante à manutenção de efeitos de atos administrativos. 
A atuação da Administração Pública sob a égide de uma ordem constitucional consagradora de princípios como a razoabilidade e a proporcionalidade, a segurança jurídica, bem como seu acesso aos direitos fundamentais constitui o fundamento para autorizar a modulação temporal dos efeitos da invalidação de atos administrativos, tal como existente no tocante à declaração de inconstitucionalidade das leis.

Semelhante prática exige a devida motivação das decisões administrativas que venham a manter, a despeito da realização da invalidação, todos ou alguns efeitos do ato viciado, de modo a propiciar a apreciação e fiscalização pela sociedade e pelos órgãos de controle da Administração Pública, sendo ainda necessário assegurar a manifestação prévia daqueles que venham a ser atingidos com referida decisão de estabilização.

\section{REFERÊNCIAS}

BRAGA, Valeschka e Silva.Princípio da razoabilidade e proporcionalidade.Curitiba: Ed. Juruá, 2003.

BRASIL, Constituição (1988). Constituição da República Federativa do Brasil, Brasília, DF, Senado, 1988.

BRASIL. Lei ${ }^{\circ}$ 8.429, de 02 de junho de 1992. Dispõe sobre as sanções aplicáveis aos agentes públicos nos casos de enriquecimento ilícito no exercício de mandato, cargo, emprego ou função na administração pública direta, indireta ou fundacional e dá outras providências. Diário Oficial da União. Brasília, DF, Disponível em: <http://www.planalto.gov.br/ccivil_03/leis/L8429.htm> Acesso em: 10 set.2016.

BRASIL. Lei no 9.784, de 29 de janeiro de 1999. Regula o processo administrativo no âmbito da Administração Pública Federal. Diário Oficial da União. Brasília, DF, Disponível em: <http://www.planalto.gov.br/ccivil_03/Leis/L9784.htm> Acesso em: 10 set.2016.

BRASIL. Lei no 12.401, de 28 de abril de 2011. Altera a Lei no 8.080, de 19 de setembro de 1990, para dispor sobre a assistência terapêutica e a incorporação de tecnologia em saúde no âmbito do Sistema Único de Saúde - SUS. Diário Oficial da União. Brasília, DF, Disponível em: <http://www.planalto.gov.br/ccivil_03/_Ato2011-2014/2011/Lei/L12401.htm> Acesso em: 10 set.2016.

BRASIL. Supremo Tribunal Federal. Embargos de Declaração no Recurso Extraordinário no 600.885 . Brasília, DF, 29 de junho de 2012. Diário de Justiça Eletrônico.

BRASIL. Supremo Tribunal Federal. Recurso Extraordinário no 78594. Brasília, DF de 2012. Diário de Justiça Eletrônico. Brasília, 22 out. 2012.

BRASIL. Supremo Tribunal Federal. Súmula no 473. Brasília, DF, 03 de dezembro de 1969. Diário de Justiça Eletrônico. Brasília. 
BRASIL. Tribunal de Contas da União. Súmula nº 106. Brasília, DF, 25 de novembro de 1976. Diário Oficial da União. Brasília.

BRASIL. Tribunal de Contas da União. Súmula no 249. Brasília, DF, 09 de maio de 2007. Diário Oficial da União. Brasília.

CARValho FILHO, José dos Santos. Processo Administrativo Federal: comentários à Lei no 9.784, de 29/1/1999. Rio de Janeiro: Lumen Juris Editora, 2001.

DWORKIN, Ronald. Taking rights seriously.Cambridge: Harvard University Press, 1999.

FURTADO, Lucas Rocha. Curso de Direito Administrativo.2. ed. Belo Horizonte: Fórum, 2010.

MARTINS. Ricardo Marcondes. Efeitos dos vícios do ato administrativo. São Paulo: Malheiros, 2008.

MEDAUAR, Odete. Direito Administrativo Moderno, São Paulo: Revista dos Tribunais, 2015.

MELLO, Celso Antonio Bandeira de. Curso de direito administrativo. 19.ed. São Paulo: Malheiros Editores, 2005.

MENDES, Gilmar Ferreira; COELHO, Inocêncio Mártires; BRANCO, Paulo Gustavo Gonet. Curso de Direito Constitucional. São Paulo: Saraiva, 2007.

MORAES, Germana de Oliveira.Controle Jurisdicional da Administração Pública. São Paulo: Malheiros, 1999.

OTERO, Paulo. Legalidade e Administração Pública: o sentido da vinculação administrativa à juridicidade. Lisboa: Almedina, 2003.

PARANÁ. Tribunal de Justiça do Estado do Paraná. ADI nº 52764-2. Curitiba, PR, 16 de setembro de 2011. Diário Oficial do Estado do Paraná. Curitiba.

SILVA, Vasco Manuel Pascoal Dias Pereira da. Em busca do acto administrativo perdido. Coimbra: Livraria Almedina, 1998.

SILVA, Clarissa Sampaio. Limites à Invalidação dos Atos Administrativos. São Paulo: Max Limonad, 2001.

SUNDFELD, Carlos Ari. Ato administrativo inválido.São Paulo: Revista dos Tribunais, 1990;

ZAGREBELSKY, Gustavo. II Diritto Mitte. Torino: Giulio Einaundi,1992. 